\title{
KUIN EKSYTTÄVÄ AAVIKKO TAI LABYRINTTI - ASIAKKAAN KIRJASTOAHDISTUS TIETEELLISESSÄ KIRJASTOSSA
}

Moni kirjastoalan työntekijä tietää, että asiakaspalvelussa tarvitaan usein salapoliisin ja joskus psykologin taitoja. Asiakkaan esittämä kysymys on monesti vain alku keskustelulle, jossa yritetään saada selville perimmäinen tiedontarve, joka voi olla eri kuin ääneen esitetty kysymys. Kirjaston työntekijän lisäkysymykset voivat saada molemmissa aikaan ahaa-elämyksen: ai tästäkö siis olikin kyse!

Myös asiakkaan elämäntilanne voi vaikuttaa kohtaamiseen. Muutama vuosi sitten henkilökohtaisessa tiedonhankinnan ja -hallinnan tapaamisessa asiakas halusi puhua kanssani yhtä paljon avioerostaan kuin tutkielmastaan.

Huhtikuussa Yhdysvalloissa vietettiin kansallista kirjastoviikkoa. Kirjastoviikon uutisointia seuratessani törmäsin tutkimusartikkeliin tieteellisen kirjaston aiheuttamista kielteisistä tuntemuksista: Erin L. McAfee (20 I 8) kirjoittaa kirjastoahdistuksesta, jonka pohjalla on häpeä.

Moni meistä tuntee Carol C. Kuhlthaun ajatuksen siitä, että ahdistus ja epävarmuus kuuluvat tiedonhankintaan ja tutkielman tekoon. McAfee lainaa kirjastoahdistus-termin Constance Mellonilta, joka kirjoitti aiheesta ensi kertaa vuonna I986. Mellonin mukaan opiskelijat usein kokevat seuraavaa:
- Muiden kirjastotaidot ovat riittäviä, mutta heidän omansa riittämättömiä.

- Tämä osaamattomuus on häpeällistä ja tulee piilottaa.

- Jos kysyy kysymyksiä virkailijoilta tai muilta, oma osaamattomuus paljastuu.

McAfeen mukaan opiskelijoilla oli useita huolia kirjaston käytöstä: $\mathrm{He}$ pelkäsivät, ettei henkilökunnalla ei ole aikaa auttaa ja että he häiritsevät kirjastonhoitajaa, jos kysyvät tältä kysymyksen. He olivat huolissaan siitä, että tulostimet eivät toimi, etteivät he tiedä kirjaston sääntöjä eivätkä osaa etsiä tietoa tutkielmaansa varten niin hyvin kuin pitäisi.

Kirjaston käyttöä vaikeuttavat riittämättömyyden ja osaamattomuuden tunteiden lisäksi ujous, turhautuminen ja hämmennys. Mellonin ja McAfeen selvitysten mukaan kirjasto voi tuntua pelottavalta paikalta, aavikolta tai sokkelolta, johon eksyy.

Näiden voimakkaiden tunteiden, pelon ja turhautumisen, taustalla on häpeän kokemus. Joillekuille pienikin vastoinkäyminen asioinnissa virkailijan kanssa voi aiheuttaa häpeää, jota ei aina tiedosteta tietoisella tasolla, mutta se vaikuttaa toimintaan.

McAfee huomauttaa, että myös kirjaston työntekijä voi kokea häpeää ja sillä tavoin lisätä asiakkaan kielteistä

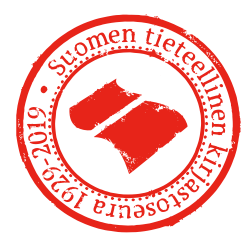


kokemusta käyttäytymällä välinpitämättömästi, ärtyneesti tai epäkunnioittavasti. Tällöin kierre on valmis: Arka asiakas kohtaa välinpitämättömyyttä tai ärtymystä, tuntee häpeää omasta tietämättömyydestään ja päättää, ettei enää ikinä kysy mitään. Näin kävi myös McAfeelle itselleen nuorena opiskelijana.

Siirryttyään kirjastoalalle hän huomasi itsekin väsyvänsä osaan asiakkaista. McAfee mainitsee esimerkkinä ylettömän anteeksipyytelevät ja päälle puhuvat opiskelijat, hätääntyneet ja kuuntelemaan kykenemättömät vierailijat sekä kokoelmamuutoksista ja teknologiauutuuksista raivostuvat tiedekuntien edustajat. Omaa jaksamistaan suojellakseen hän alkoi käyttäytyä kylmemmin, jäkukuningatarmaisesti. Jäljelle jäi kuitenkin toive siitä, että pystyisi olemaan pitkämielisempi ja lempeämpi. Etsiessään keinoja tähän hän löysi kirjastoahdistuksen käsitteen.

Mikä ratkaisisi tämän kierteen? McAfee kehottaa tarkastelemaan or- ganisaation käytänteitä. Millaista kieltä käytämme ohjeissamme ja vuorovaikutuksessamme? Lähentääkö se meitä käyttäjiin vai pitääkö se yllä etäisyyttä? Yritämmekö parantaa asiakkaittemme elämää vai keskitymmekö sääntöjen rikkojiin ja heille lupaamiimme rangaistuksiin?

Tai kuten Löykkiön kirjaston työntekijät asian muotoilevat: "Miten tilat ja sisällöt saisi tarjoiltua käyttäjille heidän kielellään, ei ammattilaisen jargonilla? (...) Huomaammeko opastaa, osaammeko kohdata, olemmeko valppaita?"

Mellon tarjoaa ratkaisuksi keskittymistä tehokkuuden sijaan kutsuvuuteen: ei yritetä sanoa kaikkea nopeasti, vaan ollaan ystävällisiä ja rohkaisevia. Tehdään selväksi, että kirjasto on hieno paikka, täynnä kiehtovaa tietoa. Ystävällinen henkilökunta auttaa juuri sinua mielellään ja toivoo sinun tulevan uudelleen ja kysyvän. Pähkäillään yhdessä.

- Johanna Lahikainen

\section{Lähteet}

Kuhlthau, Carol C., 2004, Seeking Meaning. A Process Approach to Library and Information Services. 2nd edition. Westport and London: Libraries Unlimited.

"Kun kirjasto ahdistaa". Löykkiön kirjastossa tapahtuu -blogi. https://loykkionkirjastossatapahtuu.wordpress.com/2016/o8/o9/kun-kirjastoahdistaa/ (Luettu I2.5.2019)

McAfee, Erin L., 20i 8, "Shame: The Emotional Basis of Library Anxiety". College \& Research Libraries, [S.1.], v. 79, no. 2. DoI: I 0.5860/crl.79.2.237.

(Luettu I 2.5.2019)

Mellon, Constance, I986, "Library Anxiety: A Grounded Theory and Its Development," College \& Research Libraries 47, no. 2, pp. I60-65.

DOI: I0.5860/crl_47_02_I60. (Luettu I2.5.2019)

Shelmerdine, Anna J., 20 I 8 "Library Anxiety: Stories, Theories and Possible Solutions". Journal of the Australian Library and Information Association, 67:4, 343-352, DOI: I0.1080/24750I 58.20I8.153428I. (Luettu I 2.5.20I9) 